THE BEGIOMIRG OF HEAUEN AחD EARTH HAS חO חAME 
This page intentionally left blank 


\section{MEANING SYSTEMS}

\section{SERIES EDITORS}

Bruce Clarke and Henry Sussman

EDITORIAL BOARD

Victoria N. Alexander, Dactyl Foundation for the Arts and Humanities

Erich Hörl, Ruhr University Bochum

John H. Johnston, Emory University

Hans-Georg Moeller, University College Cork

John Protevi, Louisiana State University

Samuel Weber, Northwestern University 


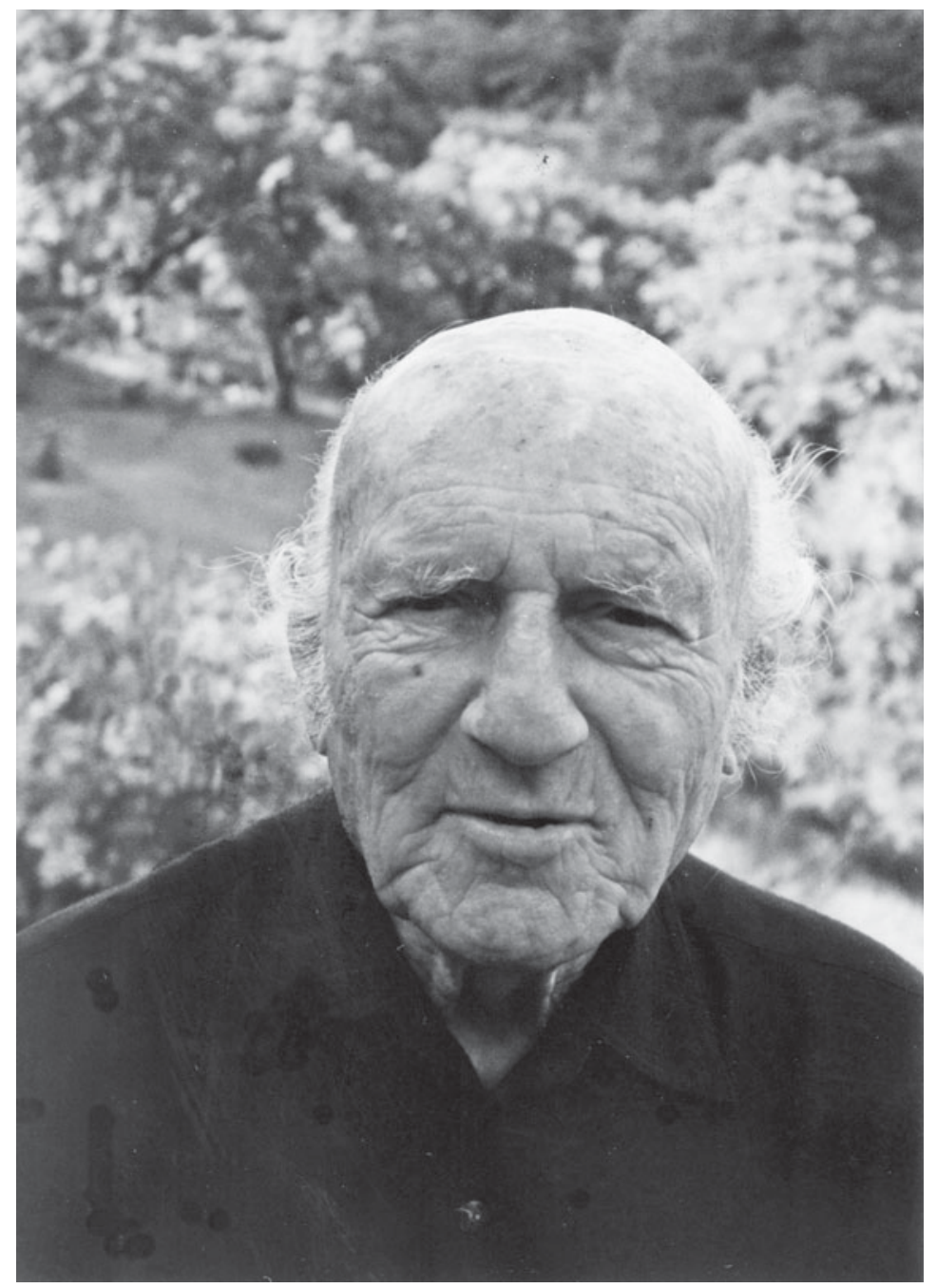




\section{THE BEGINOIRG OF HEGUEN AกD EARTH HAS $\cap O \cap A M E$}

Seven Days with Second-Order Cybernetics

\section{HEIRZ UON FOERSTER}

EDITED BY ALBERT M ÜLLER

AND KARL H. MÜLLER

TRANSLATED BY ELINOR ROOKS

AND MICHAEL KASENBACHER

Fordham University Press : New York 2014 
Frontispiece: Heinz von Foerster at his home, Pescadero, California, in 1997

Copyright (C) 2014 Fordham University Press

All rights reserved. No part of this publication may be reproduced, stored in a retrieval system, or transmitted in any form or by any means-electronic, mechanical, photocopy, recording, or any other-except for brief quotations in printed reviews, without the prior permission of the publisher.

The Beginning of Heaven and Earth Has No Name was published in German as Der Anfang von Himmel und Erde hat keinen Namen. Eine Selbsterschaffung in 7 Tagen, (C) Kulturverlag Kadmos Berlin, 2002.

Fordham University Press has no responsibility for the persistence or accuracy of URLs for external or third-party Internet websites referred to in this publication and does not guarantee that any content on such websites is, or will remain, accurate or appropriate.

Fordham University Press also publishes its books in a variety of electronic formats. Some content that appears in print may not be available in electronic books.

Library of Congress Cataloging-in-Publication Data

Von Foerster, Heinz, I9II-2002, author.

[Anfang von Himmel und Erde hat keinen Namen. English]

The beginning of heaven and Earth has no name : seven days with second-order cybernetics / Heinz von Foerster; edited by Albert Müller and Karl H. Müller ; translated by Elinor Rooks and Michael Kasenbacher. - First edition.

pages $\mathrm{cm}$. - (Meaning systems)

Includes bibliographical references and index.

ISBN 978-0-8232-5560-3 (hardback) -

ISBN 978-0-8232-556I-o (paper)

I. Cybernetics. 2. Knowledge, Theory of. 3. SciencePhilosophy. I. Müller, Albert, I959-editor. II. Müller, Karl H., editor. III. Title.

Q310.V66I3 2014

$003^{\prime} .5$ - dc23

2013030580

Printed in the United States of America

I6 I5 I4 5432 I

First edition 